\title{
COMMENTS
}

\section{Excessive Force Claims: Removing the Double Standard}

When plaintiffs allege that the police used excessive force during an arrest, courts look either to the fourth amendment's protection against unreasonable seizures, ${ }^{1}$ or to the fourteenth amendment's guarantee of due process, ${ }^{2}$ to appraise the constitutionality of the arrest procedures. ${ }^{3}$ Once an arrest has been made, however, the use of force in pretrial detainment practices is evaluated exclusively by reference to the due process standard. ${ }^{4}$

History and precedent support both standards, but the use of two different textual sources to define the constitutional limits of a single class of activity-state use of force against criminal suspects-has brought to the fore an anomalous disparity between the

1 "The right of the people to be secure in their persons . . . against unreasonable searches and seizures, shall not be violated." U.S. Const. amend. IV.

2 "[N]or shall any state deprive any person of life, liberty, or property, without due process of law. . . " U.S. Const. amend. XIV \& 1 .

3 For application of fourth amendment scrutiny, see Tennessee v. Garner, 471 U.S. 1 (1985); New v. City of Minneapolis, 792 F.2d 724 (8th Cir. 1986); Gilmere v. City of Atlanta, 774 F.2d 1495 (11th Cir. 1985) (en banc); Kidd v. O'Neil, 774 F.2d 1252 (4th Cir. 1985); Robins v. Harum, 773 F.2d 1004 (9th Cir. 1985); Wilson v. Beebe, 770 F.2d 578 (6th Cir. 1985) (en banc); Garcia v. Wyckoff, 615 F. Supp. 217 (D. Colo. 1985); Lykken v. Vavreck, 366 F. Supp. 585 (D. Minn. 1973).

For application of the due process standard, see Rochin v. California, 342 U.S. 165 (1952); New v. City of Minneapolis, 792 F.2d 724 (8th Cir. 1986); Hewett v. Ogletree, 786 F.2d 1080 (11th Cir. 1986); Fernandez v. Leonard, 784 F.2d 1209 (1st Cir. 1986); Gilmere v. City of Atlanta, 774 F.2d 1495 (11th Cir. 1985) (en banc); Gumz v. Morrissette, 772 F.2d 1395 (7th Cir. 1985); Wilson v. Beebe, 770 F.2d 578 (6th Cir. 1985) (en banc); Norris v. District of Columbia, 737 F.2d 1148 (D.C. Cir. 1984); Blake v. Katter, 693 F.2d 677 (7th Cir. 1982); Wise v. Bravo, 666 F.2d 1328 (10th Cir. 1981); Black v. Stephens, 662 F.2d 181 (3d Cir. 1981); Putnam v. Gerloff, 639 F.2d 415 (8th Cir. 1981); Shillingford v. Holmes, 634 F.2d 263 (5th Cir. 1981); Johnson v. Glick, 481 F.2d 1028 (2d Cir. 1973); Haile v. Village of Sag Harbor, 639 F. Supp. 718 (E.D. N.Y. 1986); Thomson v. Jones, 619 F. Supp. 745 (N.D. Il. 1985); Metcalf v. Long, 615 F. Supp. 1108 (D. Del. 1985).

- See Bell v. Wolfish, 441 U.S. 520 (1979); Wise, 666 F.2d at 1328; Black, 662 F.2d at 181; Glick, 481 F.2d at 1028. 
limits to police discretion that apply in the context of arrest and those that apply in the context of pretrial detainment. Under current doctrine, criminal suspects are protected from "unreasonable" police conduct during an arrest, but afterward, when the exigencies attending arrest are no longer present, detainees are shielded only from police conduct that is "malicious." In addition, the use of both standards in the arrest context has generated a redundancy in constitutional standards governing police conduct during arrest, which is especially problematic in light of the Supreme Court's recent endorsement of fourth amendment scrutiny in that context. ${ }^{6}$

This comment argues that attention to the text and history of the fourth and fourteenth amendments, as well as to the doctrines thought to illuminate them, compels adoption of an approach in which the conduct during arrest is appraised exclusively under the fourth amendment, and the use of force in all post-arrest settings is appraised under a due process standard that is informed by the rigor and objectivity of the fourth amendment approach.

The current standards for evaluating police use of force and the historical development of these standards are considered in part I, while part II examines the propriety of fourth amendment scrutiny of force used in arrest. Part III discusses the use of arrest as the threshold of due process protection, and part IV considers the standards that ought to limit permissible force in the detention context. ${ }^{7}$

\section{The Current Standards}

\section{A. Due Process Review of Police Force}

Most courts consider police use of excessive force in both arrest and detention as violative of the guarantee of due process under the fourteenth amendment. ${ }^{8}$ This analysis is premised on Rochin v. California, ${ }^{9}$ in which the Supreme Court held that the due process clause protects criminal suspects from police conduct that "shocks the conscience." In Rochin, the Court ruled that a defendant's due process rights had been violated when police

5 See text at notes $33-41$ below.

B See Garner, 471 U.S. at 3-7.

7 Throughout this comment, "detention" refers to the restraint of criminal suspects who are awaiting trial. "Arrest" refers only to the process of bringing a suspect within the state's control in the first instance.

' See cases cited in note 3 above.

342 U.S. 165 (1952).

${ }^{10} \mathrm{Id}$. at 172. 
forced an emetic into his stomach to retrieve evidence for a narcotics case. Such police tactics, Justice Frankfurter wrote, "do more than offend some fastidious squeamishness or private sentimentalism about combatting crime too energetically": they deprive basic rights that are summarized in the constitutional guarantee of due process. ${ }^{11}$

Later courts have attempted to reconcile Justice Frankfurter's broad admonition with his concurrent assertion that the Constitution does not "leave judges at large"12 and his warning that the due process protection he described should not be "turned into a destructive dogma against the states in the administration of their systems of criminal justice."13 In Johnson $v$. Glick, Judge Friendly announced a standard that has become the prevailing one in cases alleging the use of excessive force during pretrial detention:

Not every push or shove, even if it may later seem unnecessary in the peace of a judge's chambers, violates . . . constitutional rights. In determining whether the constitutional line has been crossed, a court must look to such factors as the need for the application of force, the relationship between the need and the amount of force that was used, the extent of injury inflicted, and whether force was applied in a good faith effort ... or maliciously and sadistically for the very purpose of causing harm. ${ }^{14}$

In Glick, the Second Circuit held that the "constitutional line" had been crossed by a guard's unprovoked attack on a suspect in pretrial detention. Judge Friendly asserted that this protection did not lie in any "specific" of the Bill of Rights, but rather in the protection of substantive rights embodied in the due process clause of the fourteenth amendment. ${ }^{15}$

12 Id.

12 Id. at 170.

13 Id. at 168.

34 Johnson v. Glick, 481 F.2d 1028, 1033 (2d Cir. 1973).

1s Id. at 1032. See also Logan v. United States, 144 U.S. 263 (1892) (fourteenth amendment encompasses right to be secure from state-imposed violence while in custody).

Although Judge Friendly located this protection outside the "specifics" of the Bill of Rights, other courts have located the liberty interest protected from police use of force in the due process clause of the fifth amendment as applied to the states through the fourteenth. See Kidd v. O'Neil, 774 F.2d 1252, 1259 (4th Cir. 1985). The distinction has not been adopted by circuit courts generally, and in any event it does not change the analysis herein. Compare Glick, 481 F.2d at 1032 (no mention of fifth amendment), with Ingraham v. Wright, 430 U.S. 651, 673-74 (1977) ("liberty preserved from deprivation" by fifth amendment applicable to states through fourteenth). The fourteenth amendment standard considered here presumably applies to analogous claims under the due process clause of the fifth 
Although Rochin is one of several opinions by Justice Frankfurter that looks to the due process clause to guarantee certain incidents of criminal procedure, ${ }^{18}$ Glick characterizes that guarantee as one of a substantive right. ${ }^{17}$ This identifies Judge Friendly's standard with the substantive due process doctrine, which enjoys contemporary vitality largely in cases involving rights to privacy or reproductive autonomy that the Court has determined are "fundamental" or "implicit in the concept of ordered liberty." 18 As one court of appeals has noted, this link is warranted because the right to bodily security that police force affects is "the most fundamental aspect of personal privacy"19 and so falls within that line of "substantive due process" reasoning that retains Supreme Court approval.

The due process clause provides a textual anchor for Judge Friendly's standard, but substantive due process doctrine-generally applied to review the merits of state regulation-provides little guidance for application in the very different context of excessive force allegations. As a result, some courts simply use the open-ended Glick language to decide whether the conduct alleged by the plaintiff was sufficiently egregious to violate due process rights. ${ }^{20}$ Most courts, however, have looked at the concerns exhibited by that language-severity, excessiveness, and intent-and so have derived a three-pronged standard by which to

amendment against federal officers. See, e.g., Wolfish, 441 U.S. at 535 (due process protection of federal pretrial detainees).

${ }^{18}$ See also Joint Anti-Fascist Comm. v. McGrath, 341 U.S. 123, 163 (1951) (Frankfurter, J., concurring); Solesbee v. Balkcom, 339 U.S. 9, 16 (1950) (Frankfurter, J., dissenting); Wolf v. Colorado, 338 U.S. 25, 27 (1949) (majority opinion); Malinski v. New York, 324 U.S. 401, 414 (1945) (Frankfurter, J., concurring). For analysis of Justice Frankfurter's fourteenth amendment jurisprudence, see Louis H. Pollak, Mr. Justice Frankfurter: Judgment and the Fourteenth Amendment, 67 Yale L. J. 304 (1957).

${ }_{17}$ Glick, $481 \mathrm{~F} .2 \mathrm{~d}$ at 1033 . The shift was unexplained and, as discussed in notes $115-31$ and accompanying text below, unwarranted. It has, however, become almost universally accepted. See, e.g., Fernandez v. Leonard, 784 F.2d 1209, 1215 (1st Cir. 1986) ("Although most of the pre-1976 decisions finding a due process right to be free of excessive use of force by government officials did not specify whether the right was 'substantive' or 'procedural,' we think such protection could only be substantive.").

${ }^{18}$ Rochin, 342 U.S. at 169, quoting Palko v. Connecticut, 302 U.S. 319, 325 (1937). The most renowned and recent application of the doctrine is Roe v. Wade, 410 U.S. 113 (1973), but the identification of privacy and personal autonomy with the "liberty" protected substantively by the fourteenth amendment has a considerable history. See Roe, 410 U.S. at 167-70. See also Michael J. Perry, The Constitution, the Courts, and Human Rights 117-19 (1982).

19 Hall v. Tawney, 621 F.2d 607, 613 (4th Cir. 1980). See also Youngberg v. Romeo, 457 U.S. 307, 315 (1982) ('[T] protected substantively by the Due Process Clause.").

${ }^{20}$ See, e.g., Tawney, 621 F.2d at 613. 
appraise excessive force claims: to implicate due process rights, the force used by police must (1) cause severe injury, (2) be disproportionate to the need presented, and (3) be motivated by malice rather than official zealousness. ${ }^{21}$

The requirement of severe injury comports with a federal court consensus that not every tort committed by a state officer deprives liberty protected by the fourteenth amendment. The establishment of a "constitutional line" in Glick that is higher than the threshold of state torts may be said to have anticipated Paul $v$. Davis, ${ }^{22}$ in which the Supreme Court confirmed that the due process clause could not bear this broader interpretation, as that "would make of the Fourteenth Amendment a font of tort law to be superimposed upon whatever systems may already be administered by the States." 23 It would, in short, supplant varied state common law regimes with one rigid body of constitutional tort law. Courts have reasoned further that, since the Court has held that there is no due process liberty interest in freedom from defamation or false arrest, and because Rochin itself requires shocking conduct, a simple battery by a state officer that does not cause severe injury will not suffice to establish a constitutional deprivation. ${ }^{24}$

Nonetheless, most force that results in manifest physical injury satisfies this prong of the fourteenth amendment test. Many claims arise following the use of deadly force, in which the severity and permanence of the injury is undisputed, ${ }^{25}$ but far lesser intrusions have been found to meet the standard. For instance, the District of Columbia Circuit has found nothing in Glick to suggest that the police-inflicted injury must be irremediable in order to be compensable. ${ }^{26}$ Similarly, the Fifth Circuit has held that where it is "merely fortuitous" that police force did not result in severe in-

21 See, e.g., Gumz v. Morrissette, 772 F.2d 1395, 1400 (7th Cir. 1985). See also the fourteenth amendment cases cited in note 3 above. Even those cases that do not specifically rely upon the three-pronged standard seem guided by the same criteria. For example, see Wise, 666 F.2d at 1333; Tawney, 621 F.2d at 607.

${ }^{22} 424$ U.S. 693 (1976) (denying due process claim for defamation by state official).

2s Id. at 701.

${ }^{24}$ The distinction was suggested by the "shocking to the conscience" language and by Judge Friendly's insistence that "not every push or shove" implicates a constitutional right. See Williams v. Kelley, 624 F.2d 695, 697 (5th Cir. 1980). For a similar, earlier suggestion by the Supreme Court, see Griffin v. Breckenridge, 403 U.S. 88, 101-02 (1971). For a general discussion of this issue, see Michael Wells and Thomas A. Eaton, Substantive Due Process and the Scope of Constitutional Torts, $18 \mathrm{Ga}$. L. Rev. 201 (1984).

${ }^{25}$ See, e.g., Fernandez, 784 F.2d at 1209; Gilmere, 774 F.2d at 1495; Fundiller v. City of Cooper City, 777 F.2d 1436 (11th Cir. 1985).

${ }^{26}$ Norris v. District of Columbia, 737 F.2d 1148, 1150-51 (D.C. Cir. 1984). 
jury, there may yet be a constitutional violation. ${ }^{27}$ Other demeaning and momentarily painful conduct by the police during arrest may not be compensable, ${ }^{28}$ nor may emotional distress occasioned by threatened use of deadly force; ${ }^{29}$ but allegations that wristbleeds were caused by tight handcuffs have been found to allege sufficiently severe injuries, as a matter of law, to satisfy this first prong. ${ }^{30}$

The second prong of the standard, that looking to the disproportion between the force used and the need presented by the circumstances, simply recognizes longstanding Supreme Court holdings that the due process clause contemplates use of some force when incident to a "legitimate nonpunitive governmental purpose" as long as the force is not "excessive in relation to that purpose." Injury that is an incidental and unintended consequence of such force, lower courts have noted, does not amount to the abuse of power contemplated in the due process cases. ${ }^{32}$ Thus the paradigmatic excessive force case involves police use of force after a criminal suspect has in some manner been restrained, or where, as in attacks where no arrest is contemplated, the "governmental purpose" of restraining the suspect is clearly absent.

Finally, the Glick standard holds that due process rights are not violated unless the force is used "for the very purpose of causing harm."ss Objectively unreasonable force, under this third prong, will not amount to a due process violation if used in good faith. ${ }^{34}$

Little authority other than Glick itself exists to support this last part of the standard. In Glick, ${ }^{30}$ Judge Friendly cited cases brought under 18 U.S.C $\S 242$, which provides criminal penalties for constitutional deprivations that are carried out under color of

27 Shillingford v. Holmes, 634 F.2d 263, 266 (5th Cir. 1981).

${ }^{28}$ See, e.g., Metcalf v. Long, 615 F. Supp. 1108, 1121 (D. Del. 1985) (police officer throwing plaintiff to ground and putting full body weight on him not so egregious as to constitute a due process violation).

${ }^{29}$ Contrast Black v. Stephens, 662 F.2d 181, 189 (3d Cir. 1981) (brandishing revolver near head while threatening to shoot sufficient to establish a violation), with Gumz, 772 F.2d at 1400-01 (threatening display of force not actionable).

so See, e.g., Blake v. Katter, 693 F.2d 677, 682 (7th Cir. 1982) (wristbleed from handcuffs).

s2 Wolfish, 441 U.S. at 561.

32 Rhodes v. Robinson, 612 F.2d 766, 772 (3d Cir. 1979).

ss Glick, 481 F.2d at 1033.

s4 Rhodes, 612 F.2d at 772 ("Implicit in the concept of an official's wanton and unnecessary infiction of harm is some improper state of mind."). For a case holding that simple intent, rather than malice, is all that is required, see Fernandez, 784 F.2d at 1216.

ss 481 F.2d at 1032 n.5. 
state law. ${ }^{36}$ In such cases, a constitutional deprivation is said to occur and to justify criminal sanctions when force is used for the purpose of inflicting summary punishment. ${ }^{37}$ Further support for some inquiry into state of mind can be found in recent Supreme Court decisions holding that mere negligence by a state official is insufficient to constitute a violation of due process. ${ }^{38}$

Because any use of force, even when characterized as a "regulatory restraint," may be considered punitive, federal courts have emphasized motivation in order to distinguish "shocking" conduct from mere zealousness, as Rochin requires. ${ }^{39}$ Moreover, the history of the statutes passed to enforce fourteenth amendment rights makes plain that their purpose was to redress the intentional and violent deprivation of rights. ${ }^{40}$ Some courts do not require an affirmative showing of subjective intent to punish, ${ }^{41}$ and in practice the force used by police may be sufficiently disproportionate to give rise to an inference of malice on the part of state officers.

Both Rochin and Glick concern state treatment of criminal suspects in pre-arrest detention. Judge Friendly articulated the Glick standard to provide fourteenth amendment protection to such detainees, who fall in the gap between the eighth amend-

s6 This provision is the criminal analogue of 42 U.S.C. $\$ 1983$ (1982), which provides for civil redress of constitutional violations that occur "under color of any statute, ordinance, regulation, custom, or usage of any State or Territory or the District of Columbia." Like Glick, most cases litigating the scope of fourth and fourteenth amendment protections against undue force are now brought as actions for damages under section 1983.

When federal officers deprive individuals of constitutional rights, an implied right of action similarly may be available for civil redress, notwithstanding the absence of express statutory authorization. See Bivens v. Six Unknown Fed. Narcotics Agents, 403 U.S. 388, 395-98 (1971) (damage remedy available for fourth amendment violations).

${ }^{37}$ See Williams v. United States, 341 U.S. 97, 101, 104 (1951), where, in holding that plaintiff's constitutional rights were deprived when police officers beat him in order to force his confession, Justice Douglas observed: "It is the right of the accused to be tried by a legally constituted court, not by a kangaroo court." See also Screws v. United States, 325 U.S. 91, 106 (1945) ("Those who decide to take the law into their own hands and act as prosecutor, jury, judge, and executioner plainly act to deprive a prisoner of the trial which due process of law guarantees him."); United States v. Price, 383 U.S. 787, 793 (1966).

ss See Daniels v. Williams, 106 S. Ct. 662, 663 (1986); Davidson v. Cannon, 106 S. Ct. 668 (1986). However, see the discussion in note 138 below, arguing that these cases do not prove that a showing of maliciousness is required to establish a due process violation.

30 Rochin, 342 U.S. at 172.

40 See Price, 383 U.S. at 801 (violent denial of legal process one of the reasons motivating enactment of the Civil Rights Acts). For a discussion of the legislative history of the Civil Rights Act of 1871, see Mitchum v. Foster, 407 U.S. 225, 238-42 (1972). For a survey of early fourteenth amendment cases under the pertinent statutes, see Eugene Gressman, The Unhappy History of Civil Rights Legislation, 50 Mich. L. Rev. 1323 (1952).

4 See, e.g., Fernandez, 784 F.2d at 1216 (intentional though not malicious shooting may establish due process violation). 
ment's post-conviction protections and the fourth amendment's pre-arrest safeguards. ${ }^{42}$ The Supreme Court later confirmed that the due process clause is the proper textual source of such protection in Bell v. Wolfish. ${ }^{43}$ In Wolfish, the Court appraised the constitutionality of administratively-imposed detainment practices and held that the "proper inquiry" in such cases is "whether those conditions amount to punishment of the detainee" in violation of the fourteenth amendment.44

In the district and circuit courts, however, Judge Friendly's standard has been extended beyond this narrow application to pretrial detainees. Because detainment includes all post-arrest conduct, the standard has been applied to police use of force immediately following arrest, as where a suspect is beaten after being handcuffed or otherwise restrained, or is restrained in a manner that itself causes undue injury. ${ }^{45}$ Because similar conduct may occur during arrest, courts have appraised the force used to effect an arrest by the same standard. ${ }^{46}$ The standard has also been extended to situations in which the police intend no arrest, as in Shillingford $v$. Holmes, where the plaintiff alleged that police clubbed him as he attempted to photograph the arrest of another. ${ }^{47}$

Thus, the due process standard of Glick has been extended to situations in which it overlaps with standards established under the fourth amendment. ${ }^{48}$ Extension of fourteenth amendment analysis to cases involving arrestees has occurred largely without comment and is now the current approach in a majority of the federal courts of appeals. ${ }^{49}$ The apparent assumption has been that neither Rochin, nor Glick, nor the text of the fourteenth amendment forecloses such application. Moreover, similarity of fact pat-

42 See U.S. Const. amend. VIII (prohibiting infliction of cruel and unusual punishment), amend. IV (prohibiting unreasonable searches and seizures).

43441 U.S. 520 (1979).

14 Wolfish, 441 U.S. at 535. See also Logan v. United States, 144 U.S. 263, 295 (1892) (fourteenth amendment encompasses right to be secure from unauthorized violence while in custody).

45 See, e.g., Lewis v. Downs, 774 F.2d 711, 714 (6th Cir. 1985) (per curiam) (kicking the groin of an arrestee "plainly excessive").

46 See, e.g., Hewett v. Jarrad, 786 F.2d 1080 (11th Cir. 1986) and cases cited in note 3 above employing due process analysis.

${ }^{47} 634$ F.2d 263, 264-65 (5th Cir. 1981).

48 See text at notes 60-61 below. Even the Second Circuit has broadened the application of Judge Friendly's standard. See Bellows v. Dainack, 555 F.2d 1105, 1106 n.1 (2d Cir. 1977) (policeman's use of excessive force to effect an arrest constitutes a deprivation of liberty without due process).

69 See cases cited in note 3 above. 
terns-unjustified attacks on suspects, for instance, may occur during detention in a holding cell as well as during arrest ${ }^{\text {b0 }}$-has reinforced the notion that the use of force in both contexts should be evaluated according to the same constitutional standard. In cases involving alleged excessive force during arrest, a due process claim may well be joined with fourth amendment claims, sometimes increasing the plaintiff's chances of recovery in civil rights litigation..$^{\text {s1 }}$

\section{B. Garner and Fourth Amendment Analysis of Police Force}

In Tennessee $v$. Garner, ${ }^{52}$ the Supreme Court held that the fourth amendment compels police reasonableness not only as to whether a particular seizure should be made, but also as to how the seizure is carried out. This decision has raised anew the question of whether it is appropriate to appraise the use of force during arrest according to the fourteenth amendment.

In Garner, the Court struck down a Tennessee statute which, as applied, authorized the use of deadly force against unarmed suspects in nonviolent felonies. ${ }^{53}$ The narrow holding was that police must have probable cause to believe that a suspect is dangerous or has committed a violent crime, not just that the suspect has committed a felony, before the use of deadly force may be considered reasonable under the fourth amendment. "[N]otwithstanding probable cause to seize a suspect," the Court said, "an officer may not always do so by killing him."

As important as the narrow holding in Garner is the Court's ruling that the force in arrest is to be evaluated by " balanc[ing] the nature and quality of the intrusion on the individual's Fourth Amendment interests against the importance of the governmental

so Compare Hewett, 786 F.2d at 1080 (shoulder injury incurred during detention scuffle), with Byrd v. Clark, 783 F.2d 1002 (11th Cir. 1986) (shoulder injury during arrest scuffe).

s1 Although the Supreme Court has held that a postdeprivation remedy afforded by state law may bar recovery under a procedural due process standard, Parratt v. Taylor, 451 U.S. 527 (1981), some courts have considered allegations of excessive force under a substantive due process standard, according to which postdeprivation remedies are irrelevant. See, e.g., Gilmere, 774 F.2d at 1500. For a general discussion, see Note, Due Process: Application of the Parratt Doctrine to Random and Unauthorized Deprivations of Life and Liberty, 52 Fordham L. Rev. 887 (1984), and note 131 below.

B2 471 U.S. 1 (1985).

ss Id. at 20-22. The parents of an unarmed teenage burglary subject who had been fatally shot by a Memphis police officer sought recovery under section 1983. Id. at 7 .

si Id. at 9. 
interests alleged to justify the intrusion." "\$s5 As in other fourth amendment contexts, this balancing test is an objective and factsensitive one that looks to the "totality of the circumstances" that were known to the officer at the time of the challenged conduct. The test includes some deference to an individual officer's judgment in a quickly developing situation, but the distinction drawn in Garner between violent and non-violent suspects suggests that when considering the quantum of force employed, the strength of the government's interest in making the seizure will vary primarily according to the severity of the crime attributed to the suspect..$^{56}$

Some federal courts have interpreted Garner as a change in the law, or at least a decided Supreme Court preference for fourth amendment scrutiny of excessive force claims prior to arrest. ${ }^{57} \mathrm{~A}$ strong case can be made for the proposition that Garner and other recent Supreme Court cases portend a shift away from due process analysis in the arrest context, toward an exclusive focus on the fourth amendment standard. In Garner itself, the Sixth Circuit's alternative due process rationale for striking down the challenged state statute was mentioned only in a footnote of Justice White's majority opinion. ${ }^{58}$ Furthermore, in recent years the Supreme Court has affirmed the validity of Rochin only to the extent of oblique mention in footnotes and citation in non-majority opinions. ${ }^{5 \theta}$

At the same time that Rochin's due process focus has faded to the background, the Court has addressed police conduct similar to that challenged in Rochin-invasive surgical procedure to retrieve evidence-under a fourth amendment standard. Winston v. Lee, ${ }^{60}$ in which the Court prohibited execution of a warrant to surgically remove a bullet from a criminal defendant, and Schmerber $v$. Cali-

ss Id. at 8, quoting United States v. Place, 462 U.S. 696, 703 (1983). This balancing test has its origins in the "stop and frisk" case, Terry v. Ohio, 392 U.S. 1, 28-29 (1968).

sB Contrast Garner, 471 U.S. at 11-12 (noting that the severity of the crime attributed to a suspect may control whether a seizure is reasonable), with Mincey v. Arizona, 437 U.S. 385,394 (1978) (noting that the reasonableness of a search is unchanged by the severity of the crime under investigation).

sz See, e.g., Gumz, 772 F.2d at 1404 (Easterbrook, J., concurring); Metcalf, 615 F. Supp. at 1120; Garcia v. Wyckoff, 615 F. Supp 217, 223 (D. Colo. 1985). For a list of circuits where such fourth amendment analysis is applied in the arrest context, see note 3 above.

Well before the decision in Garner, the Fourth Circuit had exhibited a preference for fourth amendment analysis of pre-arrest use of force. See Jenkins v. Averett, 424 F.2d 1228 (4th Cir. 1970).

${ }^{88}$ Garner, 471 U.S. at 6-7 n.7, quoting Garner v. Memphis Police Dept., 710 F.2d 240, 246-47 (6th Cir. 1983).

se See, e.g., Winston v. Lee, 470 U.S. 753, 105 S. Ct. 1611, 1617 n.5 (1985); Parratt v. Taylor, 451 U.S. 527, 553 n.11 (1981) (Powell, J., concurring in the result).

${ }^{80} 470$ U.S. 753, 105 S. Ct. 1611 (1985). 
fornia ${ }^{81}$ in which the Justices affirmed the admissibility of a warrantless blood test in a drunk-driving trial, suggest that the Supreme Court today would decide Rochin on fourth amendment grounds.

The shift in the analysis applied to these particular factual situations may be attributable to timing: Rochin predated application of the exclusionary rule to the states. ${ }^{62} \mathrm{~A}$ few federal judges have inferred from Winston, Schmerber, and Garner the demise of the substantive due process standard in excessive force cases. One can argue that after application of the exclusionary rule to the states for fourth amendment violations, application of substantive due process principles is merely redundant. No federal court of appeals has adopted that conclusion as law, however, and two have confirmed the validity of both fourth amendment and fourteenth amendment claims arising from undue force during arrest, in en banc decisions handed down after Garner. ${ }^{6 s}$

The divergence of views now prevailing among federal circuits was well represented on a recent Seventh Circuit panel that appraised a claim of excessive force-a panel which, while unanimous in judgment, disagreed considerably in reasoning. In Gumz v. Morrissette, ${ }^{64}$ a Wisconsin farmer sued for damages after state natural resource police used carloads of agents brandishing shotguns to arrest him for dredging without a permit. ${ }^{65}$ The district court dismissed the suit and a Seventh Circuit panel affirmed the dismissal. Judge Cummings held for the majority that the plaintiff failed to allege a serious injury as required by the due process standard derived from Glick. $^{68}$ In a concurring opinion, Judge Easterbrook reached the same result using a fourth amendment analysis. $\mathrm{He}$ urged that the circuit abandon due process analysis in light of Garner and appraise pre-arrest excessive force claims exclusively under the fourth amendment. ${ }^{67}$

Judge Easterbrook's concurrence argued that Rochin is predicated on a discredited doctrine, substantive due process, and that

a1 384 U.S. 757 (1966).

62 Justice Frankfurter himself had written the Court's opinion rejecting application of the exclusionary rule to the states. Wolf v. Colorado, 338 U.S. 25 (1949). When the Court later reversed this decision, Frankfurter joined the dissenters. Mapp v. Ohio, 367 U.S. 643, 672 (1961).

os See Gilmere, 774 F.2d at 1495 (en banc); Wilson v. Beebe, 770 F.2d 578 (6th Cir. 1985) (en banc).

of 772 F.2d 1395 (7th Cir. 1985).

os Id.

6s Id. at 1400 .

${ }^{87}$ Id. at 1405. 
"shocking to the conscience" has become "shorthand for a judicial privilege to condemn things the judges do not like or cannot understand." it asserted that " $[t]$ he notorious difficulties in defining reasonableness under the fourth amendment are insignificant compared to the randomness that flows from asking people what shocks their consciences." ${ }^{39}$ Conceding that the reasonableness inquiry may also be open-ended, Judge Easterbrook contended that its objective standard is to be preferred to the subjective "malice" and "shocks the conscience" inquiries required by due process analysis, and extolled fourth amendment doctrine as a source of more precise guidance for police conduct. ${ }^{70}$ Here he echoed Justice O'Connor, who stressed the need for bright-line constitutional safeguards in her dissent in Garner. ${ }^{71}$ Judge Easterbrook continued:

There is now a tremendous body of precedent dealing with searches and seizures, and these cases furnish rules that ought to be sufficient guidance in a case such as this. Yet a "shocks the conscience" test spurns bright lines. It spurns rules. It is a vague standard . . . inviting decisionmakers to consult their sensibilities rather than objective circumstances. ${ }^{72}$

Finally, the concurring opinion noted that the Supreme Court had eliminated subjective motive inquiries in the related context of official immunity, and that fourth amendment reasonableness similarly precluded such an inquiry. Maliciousness was of constitutional relevance in the context of police conduct, the judge concluded, only where used to label what was objectively unreasonable conduct. ${ }^{73}$

Neither the Seventh Circuit nor any other federal circuit has responded to these arguments or to Garner with a self-conscious abandonment of due process scrutiny where excessive force during arrest is alleged; yet the approach urged by Judge Easterbrook-appraising excessive force in arrest exclusively under the fourth amendment-has long been the law of the Fourth Circuit. ${ }^{74}$

es Id. at 1406.

Id.

70 Id. at 1407.

${ }^{71}$ Garner, 471 U.S. at 22 (O'Connor, J., dissenting) ("[t]he Court's silence on critical factors in the decision to use deadly force simply invites second guessing of difficult police decisions that must be made quickly in the most trying of circumstances").

${ }^{72}$ Gumz, 772 F.2d at 1407.

73 Id.

${ }^{74}$ See, e.g., Kidd v. O'Neil, 774 F.2d 1252 (4th Cir. 1985); Jenkins v. Averett, 424 F.2d 1228, 1232 (4th Cir. 1970). But see Hall v. Tawney, 621 F.2d 607 (4th Cir. 1980), which 
In a recent opinion that noted Rochin and its progeny, Judge Phillips stated that the interests protected by the due process clause and the fourth amendment "are not perfectly congruent," and he reaffirmed the court's exclusive use of fourth amendment standards when constitutional claims address the method of search or arrest. $^{78}$ In accord with Judge Easterbrook, Judge Phillips concluded that any doubts about the rectitude of such an approach have been "laid to rest by . . . Tennessee v. Garner."

Many of the criticisms leveled at the subjective due process standard are as pertinent to its application to detention practices as to its application to arrest. Yet no court has applied fourth amendment standards beyond the context of arrest. This is so for essentially three reasons: the text of the fourth amendment seems singularly directed to arrest and not to detainment; ${ }^{78}$ the Supreme Court has largely foreclosed extension of the amendment's protection to detainees; ${ }^{78}$ and the Court also has endorsed the due process clause as the correct source for protection of detainees' bodily security, ${ }^{80}$ an approach supported by the entire Court. ${ }^{81}$

Deference to precedent hardly suffices, however, to conceal the challenge that the logic of Gumz poses to substantive due process standards in both arrest and detainment. If the criticisms advanced against Glick and its progeny are apt, they may well spell the demise of Wolfish and the other post-arrest cases as well as of Rochin.

\section{Dual Standards in Arrest Considered}

\section{A. Displacement of Due Process Claims in Arrest After Garner}

The continued application of both due process doctrine and fourth amendment principles to claims of excessive force during arrest raises the issue of why courts retain apparently redundant constitutional protection for arrestees in such cases. There are

applies a substantive due process test.

78 Kidd, 774 F.2d at 1260 . While the opinion does not attack the due process approach directly, there is a tone of skepticism in the court's treatment of substantive due process. See id. at 1258-61 \& nn. 8-12.

76 Id. at 1258.

II. at 1255 .

7s See id. at 1254-55.

79 See Hudson v. Palmer, 468 U.S. 517, 523-28 (1984), and notes 106-08 and accompanying text below.

so See Wolfish, 441 U.S. at 535; Block v. Rutherford, 468 U.S. 576, 583-85 (1984).

s1 See Wolfish, 441 U.S. at 535 (majority opinion of Rehnquist, J.), 564 (Marshall, J., dissenting), 579 (Stevens, J., dissenting). 
some contexts-custodial interrogation is one-in which more than one constitutional right may be implicated by police conduct. ${ }^{82}$ However, the courts must still account for the invocation of the controversial substantive due process doctrine in contexts where the fourth amendment explicitly compels the reasonableness of seizures.

The explanation offered for this redundancy by opponents of the substantive due process doctrine-including Judge Easterbrook-is that the doctrine veils subjective judicial preferences. The subjectivity in the end disfavors the police: because they lack clear guidance, ${ }^{83}$ they may be deterred from using force in justifiable situations for fear of offending a judge's sensibilities. But in the context of arrest, a comparison of the requirements of each standard calls into question any conclusion that the due process standard gives too little protection to police conduct. The fourth amendment prohibits unreasonable police conduct, whereas the fourteenth amendment standard articulated in Glick insists that unreasonable conduct is not necessarily unconstitutional: police conduct must be either malicious or sadistic in order to violate the Constitution. ${ }^{84}$ Rochin requires at least as much, looking to conduct that is "shocking" to one of "hardened sensibilities." apart from any overdeterrent effect of uncertainty, the substantive due process standard gives greater protection to police conduct than does the fourth amendment approach.

It might be argued in response that the due process tests simply function as labels for what is objectively unreasonable conduct. ${ }^{86}$ The Fourth Circuit has noted that the "formulation of constitutional standards in those cases, employing such terms as 'inhumane,' 'malicious,' 'sadistic,' 'shocking to the conscience,' etc., are properly understood ... a as descriptives of degrees of force that inevitably exceed those degrees 'privileged' in the various contexts." or the quantum of force the officer uses during arrest, the plain meaning of the terms employed, in both common and judicial par-

82 See Dunaway v. New York, 442 U.S. 200 (1979) (discussing point at which arrest safeguards attach under the fourth and fourteenth amendments).

8s See, e.g., Gumz, 772 F.2d at 1406-07 (Easterbrook, J., concurring) (substantive due process injects subjective standards into the analysis and thereby denies the police clear guidance.).

st Glick, 481 F.2d at 1033. See text accompanying notes 33-41 above.

ss Rochin, 342 U.S. at 172.

so For example, see Gumz, 772 F.2d at 1404 (Easterbrook, J., concurring).

${ }^{87}$ Kidd, 774 F.2d at 1261. 
lance, requires a greater showing of disproportion to establish "shocking," as opposed to merely unreasonable, conduct.

Similarly, "severe injury" is required to satisfy the fourteenth amendment standard, whereas damages are recoverable in the fourth amendment context even when no physical injury is alleged at all. ${ }^{88}$ Presumably, this would apply to seizures as well as searches.

The remaining prong of the due process standard-force disproportionate to the need presented-is analytically no different from the fourth amendment standard of reasonableness. In fact, when appraising the quantum of force employed by the police to effect an arrest, cases decided under the Glick standard often import the language of fourth amendment decisions. ${ }^{89}$ Conduct that is patently unreasonable under fourth amendment scrutiny therefore may meet only one prong of the Glick standard. Thus, contrary to the suggestions of some, the due process standard as articulated in Glick is an unlikely means of effecting a judicial agenda to hamstring the police.

This may be seen by considering the facts of Courtney $v$. Reeves, ${ }^{90}$ a Fifth Circuit case in which an arrestee alleged that a policeman shot him repeatedly after the arrestee had dropped his weapon. Under Garner, this would amount to a constitutional deprivation if the force used was excessive in relation to the government's interest in seizing the arrestee, regardless of the officer's good faith in believing the force was necessary and regardless of whether the injury inflicted would be deemed severe. Under Glick, an unreasonable but good faith belief by the officer that such force was necessary would preclude recovery under the fourteenth amendment, as would the absence of severe injury. Similarly, in Garner, the good faith of the police officer was not at issue in allowing recovery for the fourth amendment claim. But under the fourteenth amendment approach, the plaintiff would have been required to prove maliciousness or bad faith to recover in most federal courts. ${ }^{91}$

ss See, e.g., Monroe v. Pape, 365 U.S. 167 (1961).

so See, e.g., Lewis, 774 F.2d at 714, which cites language from a fourth amendment case, United States v. Sharpe, 470 U.S. 675 (1985), to support fourteenth amendment evaluation of force.

${ }^{\circ 0} 635$ F.2d 326 (5th Cir. 1981) (per curiam) (vacating district court's dismissal of prisoner's habeas corpus suit and remanding).

-1 See Gilmere v. City of Atlanta, 737 F.2d 894, 900 n.12 (11th Cir. 1984) ("fourth amendment claim fell because . . . the officers had probable cause to arrest"), aff'd in part, rev'd in part, vacated in part, and remanded, 774 F.2d 1495 (11th Cir. 1985) (en banc). 
Initially, extension of the due process standard to arrest may have expanded remedies for arrestees. Prior to Garner some courts doubted whether there could be a fourth amendment violation where police had probable cause to arrest. Fourth amendment doctrine, notwithstanding Terry $v$. Ohio, ${ }^{92}$ seemed predominantly concerned with the threshold question of whether an arrest was supported by probable cause, and not with how the police effected an otherwise valid arrest. ${ }^{93}$ Moreover, had the fourth amendment reasonableness test been applied as in the search context, Court holdings that fourth amendment analysis ought not to vary with the severity of the crime alleged would probably have limited recovery: the permitted quantum of force to arrest would presumably have been the same for both violent and non-violent felons. ${ }^{94}$ As these areas of doubt were eliminated by Garner, they no longer provide a basis for retention of due process scrutiny of force used in arrest.

One possible explanation for the persistence of the more restrictive fourteenth amendment standard is that once the standard was adopted as the law of a circuit prior to Garner, the precedential value of prior cases has continued to inform judicial application of the standard and so has led to its retention. Given the number of circuits using the due process approach, there is a considerable body of case law upon which to draw.

There is, however, an alternative and more cynical explanation for retention of the standard: disingenuous application of the Glick criteria may permit the intervention of judicial sensibilities in the manner that critics of the due process approach, such as Judge Easterbrook, suggest. The apparent lack of consistency in applying the criteria lends some support to this suggestion, ${ }^{95}$ but there are no cases in which both standards were applied and the fourteenth amendment standard produced a different result than the Garner fourth amendment standard. ${ }^{96}$ It may be, however, that the

92 392 U.S. 1 (1968); see note 53 and accompanying text above. While Baker v. McCollan, 443 U.S. 137, 145-46 (1979), had suggested that section 1983 recovery required either an attack on the validity of an arrest warrant or the absence of probable cause, this part of the holding seems now restricted to false arrest claims by Garner, 471 U.S. at 7-8.

9s The state of Tennessee made this argument in Garner, but the Court rejected it. 471 U.S. at 7-8 (reasonableness depends not only upon when the arrest is made but also upon how it is made). Still, there was considerable support for such a reading of fourth amendment case law. Brief for Appellant at 15-20, Tennessee v. Garner, 471 U.S. 1 (1985) (available on Lexis).

94 See notes 55-56 and accompanying text above.

${ }^{95}$ See notes 25-41 and accompanying text above.

96 This is true if one excludes those cases in which the fourth amendment was presumed unavailable because of the existence of probable cause, or where a fourth amendment 
"shocking to the conscience" standard informs the "reasonableness" inquiry required under the fourth amendment; a judge whose conscience is not offended by the challenged police conduct may be less likely to deem such conduct "unreasonable." In this way, the fourteenth amendment standard may indirectly influence fourth amendment analysis. This cynical explanation for the retention of a due process standard is not provable, though, as it relies on conjecture about judicial motives not expressed in opinions.

\section{B. The Fourth Amendment as the Exclusive Standard in Arrest}

Separate due process analysis of claims of excessive force in arrest should be eliminated. The due process clause guarantees certain incidents of procedure in the arrest context, but these protections are explicitly embodied in the fourth amendment itself. The Court now clearly pays little or no heed to claims of due process when they are substantially identical to claims under a particularized guarantee in the Bill of Rights. ${ }^{97}$ Thus, the only pertinence of the due process clause to arrest cases is through the doctrine of incorporation, which makes the fourth amendment's provisions applicable to state action.

Because Garner endorsed a standard in arrest that is more restrictive of police conduct than is the Glick standard, elimination of due process claims in arrest cases is proper if not required. The Court's failure to address due process issues in Garner, and its similar recent refusal to supplement eighth amendment standards with Rochin due process inquiry in cases involving prison security measures, ${ }^{88}$ suggest that the double standard the majority of circuits now favor is erroneous. As enunciated in Glick, the due process test prohibits only more extreme police conduct than that already prohibited under the fourth amendment, while it does not condemn any conduct that the fourth amendment test would permit. If the fourth amendment prohibits the lesser intrusion, it surely prohibits the greater; conduct that "shocks the conscience" or "affords brutality the cloak of law" surely cannot be reasonable under the fourth amendment.99 The lower courts' application of

claim was not properly before the court on appeal, as was the case in Gumz, 772 F.2d at 1399 n.3.

${ }^{97}$ For arguments supporting this trend, consider Whitley v. Albers, $106 \mathrm{~S}$. Ct. 1078, 1088 (1986); Gumz, 772 F.2d at 1404 (Easterbrook, J., concurring).

ss See Whitley, 106 S.Ct. at 1088.

99 The Supreme Court similarly has pointed out the absurdity of such dual standards in the eighth amendment context: "It would indeed be surprising if . . . 'conduct that shocks the conscience' or 'affords brutality the cloak of law,' and so violates the Fourteenth 
due process review in arrest cases may be more than just redundant; the due process standard could "spill over" and reduce fourth amendment protection against police misconduct.

However, the fourth amendment standard is not trouble-free. Its purported objectivity is subject to attack: balancing the government's interest in the level of force employed and the intrusion on the individual's dignitary interests by such force requires the assignment of values to the respective interests. The appeal of the fourth amendment as a source of bright-line rules is limited, too. One commentator has noted that the balancing test may be "too manipulable for fair and predictable enforcement if officers [must] distinguish between different levels of privacy, public need, intrusiveness, and types of justifications." ${ }^{100}$ Yet the open-endedness of the reasonableness inquiry is mitigated by the existence of considerable Supreme Court precedent to guide it. ${ }^{101} \mathrm{By}$ contrast, the vague contours ${ }^{102}$ of the due process clause are not given form in this context by the Supreme Court's body of substantive due process precedent, since most substantive due process cases involve review of legislative determinations. ${ }^{103}$

Moreover, the difficulties presented by fourth amendment analysis seem no greater than those inherent in objectively determining negligence. The centrality of the reasonableness inquiry in tort law certainly demonstrates the institutional competence of judges and juries to make such an objective determination. The ability of "a neutral and detached magistrate,"104 removed from "the often competitive enterprise of ferreting out crime," make reasonableness determinations is now undisputed in search cases too. The determination seems no more problematic in seizure cases. Indeed, Garner clearly affirms the Court's confidence in the institutional competence of the judiciary to evaluate objectively the quantum of force employed by the police.

Amendment, ... . were not also [cruel and unusual] punishment . . . in violation of the Eighth." Whitley, 106 S. Ct. at 1088 (citations omitted).

${ }^{100}$ Note, The Civil and Criminal Methodologies of the Fourth Amendment, 93 Yale L. J. 1127 (1984). For a general discussion, see Albert W. Alschuler, Bright Line Fever and the Fourth Amendment, 45 U. Pitt. L. Rev. 227 (1984) (arguing in favor of a case by case adjudication rather than categorical rules). See also Garner, 471 U.S. at 22-33 (O'Connor, J., dissenting) (arguing for bright line rule).

${ }_{101}$ Gumz, 772 F.2d at 1404 (Easterbrook, J., concurring).

102 See text at note 20.

${ }^{103}$ Id.

104 Coolidge v. New Hampshire, 403 U.S. 443, 449 (1971), quoting Johnson v. United States, 333 U.S. 10, 13-14 (1948).

${ }^{10 s}$ Coolidge, 403 U.S. at 449 , quoting Johnson, 333 U.S. at 13-14. 


\section{Arrest As The Due Process Threshold}

Fourth amendment scrutiny proscribes less egregious police conduct during arrest than does the due process standard as currently formulated. The latter standard thus is superfluous. If the "shocking to the conscience" standard is applied literally by the courts, police force will trigger the fourth amendment long before the due process clause is deemed violated, since "shocking" behavior always should be deemed unreasonable.

Yet due process protection will not be redundant in the detainment context. There is not yet a Court consensus that the fourth amendment protects lawfully arrested detainees at all, and there is a considerable body of opinion to the contrary. In Bell $v$. Wolfish, for example, the Court upheld the constitutionality of detainment searches, but Justice Rehnquist was careful not to admit that pretrial detainees necessarily retain any fourth amendment privacy rights. ${ }^{108} \mathrm{His}$ majority opinion deliberately pointed out that he was simply "assuming for present purposes" that the detainee enjoyed the protection of the fourth amendment. ${ }^{107}$ Even before Wolfish, Justice Powell maintained that an "essential premise" of numerous cases involving post-arrest claims premised on the fourth amendment was "that an individual lawfully subjected to a custodial arrest retains no significant Fourth Amendment interest in the privacy of his person."

This strong doubt as to the applicability of the fourth amendment to detainees must be contrasted with the Court's unrelenting insistence that the due process clause is the appropriate textual source of a detainee's protection from punishment-indeed, that due process protection from punishment is the central inquiry in

${ }^{208}$ Wolfish, 441 U.S. at 558. The Court held that "any reasonable expectation of privacy that a detainee retained necessarily would be of a diminished scope." Id. at 557-58. In Hudson v. Palmer, 468 U.S. 517 (1984), Justice O'Connor wrote in a concurring opinion that prisoners, as distinct from pre-conviction detainees, do not even enjoy this diminished protection as to their effects, arguing that "[t]he fact of arrest and incarceration abates all legitimate Fourth Amendment privacy and possessory interests in personal effects." Id. at 555. The dissent, however, insisted that the majority "believes that at least a prisoner's 'person' is secure from unreasonable search and seizure." Id. at 555 n.31 (Stevens, J., concurring in part and dissenting in part). See generally Yale Kamisar, Wayne R. LaFave, and Jerold H. Israel, Modern Criminal Procedure 246-47 \& nn. c, d (6th ed. 1986).

${ }^{107}$ Wolfish, 441 U.S. at 558, 557. Rehnquist also noted that "[i]t may well be argued that a person confined in a detention facility has no reasonable expectation of privacy with respect to his room or his cell and that therefore the Fourth Amendment provides no protection for such a person." Id. at 556-57 (citation omitted).

${ }^{108}$ United States v. Robinson, 414 U.S. 218, 237 (1973) (Powell, J., concurring). 
constitutional review of detainment practices and conditions. ${ }^{109}$ Even Justice Rehnquist, whose aversion to substantive due process doctrine was well-articulated in Roe $v$. Wade, ${ }^{110}$ authored a majority opinion that located protection of the detainee against police force in the due process clause. ${ }^{111}$ Clearly the Court will hold to the view that the due process clause has an independent function in review of detainment practices.

The best approach therefore must be one in which formal arrest is the threshold for due process protection. The fourth amendment reasonableness approach, balancing the quantum of force employed against the asserted state justification for its use, should be used to appraise police use of force during arrest; when the arrest is complete and that protection is at an end, the due process clause should be invoked to protect the detainee.

Of course, there will be difficult cases in which doubt will exist as to whether a formal arrest has been completed. Yet other constitutional safeguards are triggered by similar events, such as custodial interrogation, ${ }^{112}$ and the case law thus generated may be useful in evaluating which of the two amendments should apply. ${ }^{113}$ Another potential problem exists when police use excessive force in a situation where they intend no arrest, raising a doubt that fourth amendment standards should apply. The Supreme Court, however, has held that a "seizure" takes place whenever the police interfere with an individual's ability to walk away, ${ }^{114}$ so police violence

${ }^{109}$ See Wolfish, 441 U.S. at 535-36 and cases cited therein. This view again attracted a majority in Block v. Rutherford, 468 U.S. 576 (1984), a case in which every member of the Court located the protection of detainees in the due process clause. See id. at 583 (Burger, J.), 592 (Blackmun, J., concurring), 596 (Marshall, J., dissenting). Although Block involved searches and general detainment conditions, the same analysis should apply to excessive force claims.

$110410_{n}$ U.S. 113, 173-77 (1973) (Rehnquist, J., dissenting).

111 Wolfish, 441 U.S. at 535 n.16. Note here the contrast to the arrest context; in Garner the Court gave no heed to the due process claim. Garner, 471 U.S. at 6-7 n.7. See generally text accompanying note 58 above.

${ }^{112}$ See Dunaway v. New York, 442 U.S. 200, 206-16 (1979) (discussing when safeguards against illegal arrest attach); Miranda v. Arizona, 384 U.S. 436, 477 (1966) (safeguards against compelled self-incrimination and limited fifth amendment right to an attorney attach when individual is taken into custody or is "otherwise deprived of his freedom of action in any significant way").

213 The distinction would be largely academic under the approach proposed below in text following note 154 . The distinction would only determine the textual source of protection, rather than the applicable standards, because the post-arrest due process standard would echo the fourth amendment reasonableness inquiry.

${ }^{114}$ United States v. Brignoni-Ponce, 422 U.S. 873, 878 (1975), citing Terry, 392 U.S. at 16 ("[W]henever a police officer accosts an individual and restrains his freedom to walk away, he has 'seized' that person."). 
against those the police do not intend to arrest surely comes within Garner's fourth amendment protection.

Establishing arrest as the threshold of due process protection solves the problem of double standards applied to the use of force during arrest, and it is faithful to the Supreme Court's holding in Wolfish that the due process clause of the fourteenth amendment is properly looked to as the source of constitutional protection of detainees against excessive police force.

However, this approach and the reasoning of Garner address but a part of the problem of police use of force. The doctrinal weakness of "substantive due process" lingers, and the other criticisms leveled at due process scrutiny seem no less compelling in the detainment context than in the arrest context. In fact, one must ask further why suspects during arrest are protected (by the fourth amendment) against "unreasonable" conduct, while detainees receive protection only against "malicious" or "shocking" conduct under the due process test. In some ways, it would seem, the arrest standard should be more deferential than the detainment standard. The exigencies of arrest and the need to defer to an officer's judgment in a quickly developing situation are indisputably diminished in the detainment context; there is no apparent reason for affording the officer greater discretion in that context. While the bifurcated approach contemplates that the due process clause should be the source of protection for detainees, the content of that protection should be reexamined and modified to reduce or eliminate these problems.

\section{Toward a Credible Dug Process Standard}

\section{A. The Use of Excessive Force: A Matter of Procedure}

As troublesome as the application of due process criteria is its questionable doctrinal foundation. Judge Easterbrook in Gumz launched his attack on the substantive due process approach by identifying it as a holdover from the Lochner era, with "no pedigree other than a trail of defunct, little-mourned, and sometimes (as in Dred Scott) pernicious doctrines."115 But to concede the weakness of substantive due process as a constitutional doctrine hardly divests the due process clause of pertinence to police use of force.

${ }^{115}$ Gumz, 772 F.2d at 1406 (concurring opinion). Another persistent critic of the "shocking to the conscience" standard of due process adjudication was Justice Black. For a prime example, see Goldberg v. Kelly, 397 U.S. 254, 276-77 (1970) (Black, J., dissenting). 
Police use of force is clearly an incident of the procedure utilized to enforce penal statutes; substantive due process denotes judicial scrutiny of the policy choices reflected in the penal statutes themselves. ${ }^{118}$ When police can mete out punishment through the detention process in advance of trial, the state's procedure for enforcement of the substantive law has been circumvented. Because summary punishment contains an inherent procedural deficiency, it requires no extraordinary doctrine of "substantive due process" to bring such conduct within the harms reached by the due process clause. ${ }^{117}$ Punishment before trial is a failure of process.

Whether courts insist that they are exercising "substantive" review turns out to matter a great deal, not only for remedial issues, ${ }^{118}$ but also, as Professor Ely notes, "because of the negative feedback effect the notion of substantive due process seems to be having on the proper function of the Due Process Clause, that of guaranteeing fair procedures."119 This feedback was apparent in Gumz, in which Judge Easterbrook asserted that the plaintiff was not claiming a procedural deficiency, but was asserting a "substantive right to be free from intentional infliction of emotional distress in the course of being arrested."120 Yet the judge conceded that cases "where the police acted as judge, jury, and executioner, pose a different problem. A claim that the police never made a lawful arrest, or that after arrest the police skipped the trial on the way to the punishment, is within the central meaning of due process."121

The opinion typifies the "negative feedback" problem Professor Ely identified. Judge Easterbrook's focus on the weakness of "substantive due process" leads him to ignore that the excessive force case fits directly within his "central meaning" of due process. The underlying concern when police use excessive force is precisely that the police have been able to "skip the trial" and proceed di-

116 See note 18 and accompanying text above. See generally John Hart Ely, Democracy and Distrust: A Theory of Judicial Review 14-21 (1980); Perry, Constitution, Courts, and Human Rights at 117 n.* (cited in note 18); Raoul Berger, Government by Judiciary: The Transformation of the Fourteenth Amendment (1977).

${ }^{117}$ One Justice has noted that procedural rights are implicated by detainment practices. In Block, 468 U.S. at 576, the Court largely reiterated the analysis of Wolfish in evaluating a detainee's claims, but Justice Blackmun pointed out that the majority's analysis should have followed the Court's procedural due process doctrine. Id. at 592-96 (Blackmun, J. concurring). Block, however, did not involve any excessive force claims.

11 See note 131 below.

110 Ely, Democracy and Distrust at 19 (cited in note 116).

${ }^{120}$ Gumz, 772 F.2d at 1405 (concurring opinion).

132 Id. See also Jackson v. City of Joliet, 715 F.2d 1200, 1204 (7th Cir. 1983). 
rectly to punishing the detainee. The paradigmatic excessive force complaint-involving assault on a detainee-raises the identical issue. In other contexts, Judge Easterbrook has noted that even the "rather tame creature" of due process as that concept was understood under the Magna Carta included the right to information, indictment, and trial, ${ }^{122}$ all interests that are effectively frustrated when police punish in advance of a guilty verdict.

Thus, even if the oxymoron of "substantive due process" is to be discarded, the due process clause may nevertheless be invoked to review police conduct in cases like Glick and its progeny. Due process review in such cases, putting to one side the persistence of the term "substantive," is far removed from judicial review of the substantive merits of social or economic regulation. ${ }^{123}$ As Professor Charles Black has pointed out, judicial scrutiny of criminal procedure under the clause is appropriate precisely because legislatures cannot effectively assess the discretion exercised by policemen or prosecutors in individual instances. ${ }^{124}$ Judicial scrutiny therefore does not usurp the legislative power to make policy choices; the due process clause instead contemplates judicially imposed limits on the manner in which administrative discretion is exercised, even where the "administrators" happen to be the police. ${ }^{125}$ This has traditionally been considered the proper realm of procedure. ${ }^{126}$

The notion that the use of excessive force manifests a procedural deficiency also remains entirely faithful to Rochin, the case on which Glick and its progeny rely. Justice Frankfurter's opinion for the Court in Rochin is riddled with citation to precedent defining the procedural minima demanded by the due process clause in criminal cases. ${ }^{127}$ The doctrinal shift to substantive due process in

122 Frank H. Easterbrook, Substance and Due Process, 1982 S. Ct. Rev. 85, 97.

123 The more attentively one examines the history of due process, the more certain it appears that summary punishment is among the evils it addresses. See Keith Jurow, Untimely Thoughts: A Reconsideration of the Origins of Due Process of Law, 19 Amer. J. Legal Hist. 265 (1975); Charles E. Shattuck, The True Meaning of the Term 'Liberty' in those Clauses in the Federal and State Constitutions Which Protect 'Life, Liberty and Property,' 4 Harv. L. Rev. 365, 382 (1891) (arguing that traditional sense of "liberty" was freedom from restraint in the criminal process).

${ }^{224}$ Charles I. Black, Structure and Relationship in Constitutional Law 88-90 (1969). For further conceptual development of the structural factors that connect the due process clause with discretionary acts by state officers, see Laurence H. Tribe, Structural Due Process, 10 Harv. Civil Rts.-Civil Lib. L. Rev. 269 (1975).

${ }^{125}$ For general discussion, see Kenneth Culp Davis, Police Discretion (1975).

${ }^{226}$ See, e.g., Southern Ry. Co. v. Virginia, 290 U.S. 190 (1933) (federal courts may intervene in state regulatory matters to ensure due process standards are met).

137 Rochin, 342 U.S. at 169. Frankfurter's attempt to put Rochin in line with other cases involving procedure was consonant with his view that "[t]he history of liberty has 
Glick $k^{128}$ therefore would appear at least partially to contradict the Supreme Court case cited most often to support it.

Some courts have concluded that excessive force claims must implicate substantive due process because the "governmental conduct would remain unjustified even if it were accompanied by the most stringent of procedural safeguards." ${ }^{129}$ But there is a circularity about this analysis. The government conduct (the excess force) itself is a short-circuit of procedural safeguards; the state is punishing the criminal suspect without a guilty verdict. ${ }^{130}$ One may semantically transform the procedural notion that the state may not punish in advance of trial into a claim of a substantive right to be free of summary punishment no matter what process is offered. However, in either case it is the procedure contemplated by the Constitution-the criminal trial-that has been flouted. The substantive content of the underlying criminal statute is nowhere at issue. ${ }^{131}$

\section{B. Implications of Garner}

The disparity between the constitutional protections afforded arrestees and those afforded detainees necessitates further consideration of the due process standard that the circuit courts have developed since Glick. This examination reveals the arbitrary nature of two of the three criteria now used by the courts in due process cases. Once one understands that limits on excessive force are procedural guarantees against punishment before trial, it be-

largely been the history of the observance of procedural safeguards." McNabb, 318 U.S. at 347 (Frankfurter, J.). See note 16 above and the opinions cited therein.

128 See notes 17-19 and accompanying text above.

128 Gilmere v. City of Atlanta, 774 F.2d 1495, 1500 (11th Cir. 1985) (en banc) (excessive force used during arrest violates substantive due process).

${ }^{130}$ The Supreme Court has consistently held that eighth amendment safeguards do not attach until formal adjudication of guilt. Wolfish, 441 U.S. at 535 n.16.

${ }^{131}$ Procedural due process, as currently defined by the Court, has one wrinkle that is not present in substantive due process analysis: postdeprivation remedies such as tort suits may supply all the process that is due and thus defeat any claim of constitutional deprivation. See Parratt v. Taylor, 451 U.S. 527, 543-44 (1981). The continued force of the Parratt decision is, however, uncertain after the Court's decision in Daniels v. Williams, $106 \mathrm{~S}$. Ct. 662, 663 (1986), in which it partially overruled Parratt in holding that negligent conduct by state officials is not constitutionally objectionable. Moreover, at least one court has interpreted this holding to apply only to insignificant claims, as Parratt involved the loss of only a hobby kit. See Gilmere, 774 F.2d at 1498 n.3. The Court has not yet decided whether a postdeprivation remedy will satisfy the due process clause when a liberty interest is at stake. Although the Court held in Ingraham v. Wright, 430 U.S. 651 (1977), that postdeprivation remedies satisfied due process when corporal punishment in schools operated to deprive students of liberty interests, the opinion appears heavily influenced by the long historical background and widespread approval of corporal punishment. Id. at 660-63, 676, 681 . 
comes plain that the severity of injury and the officer's state of mind should not count in the due process analysis.

The "severe injury" prong of the standard, however faithfully it may be applied, ${ }^{132}$ is not a basis on which the Supreme Court generally has distinguished violations of constitutional rights from state torts. In parallel areas where due process limitations control criminal procedure-suggestiveness of police lineups and voluntariness of confessions, for example--severity of injury is not a relevant inquiry. ${ }^{133}$ In Wolfish, moreover, physical injury was not identified as a necessary element of a due process challenge to police detainment practices. ${ }^{194}$

The second prong of the current due process standard, the requirement of subjective malice or intent to punish, is questionable for both its subjectivity and its irrelevance to the protection of due process rights. ${ }^{185}$ The only authorities cited for the requirement are criminal cases brought under 18 U.S.C. $\S 242$ (the criminal analogue to 42 U.S.C. $\S 1983$ ), in which the Court inferred an intent requirement in the face of allegations that the statute was void for vagueness. ${ }^{136}$ More recently the Court, in substantive review of state legislation, has noted in dictum the irrelevance of using an officer's claim of good faith as the basis for deciding whether due process rights have been violated in a particular case. ${ }^{137}$

As Justice Marshall suggested in Wolfish, an enormous but good faith belief in the need for excess is characteristic of law enforcement. ${ }^{138}$ Such zeal should not be constitutionally protected

132 See notes $25-30$ and accompanying text above.

1ss See, e.g., Stovall v. Denno, 388 U.S. 293 (1967) (police lineups); Spano v. New York, 360 U.S. 315, 321 (1959) (police confessions).

The lineup and confession safeguards offered by the due process clause are arguably distinguishable from the limits on police force because they implicate the accuracy of the factfinding process. Permitting summary punishment through police use of excessive force, however, plainly undermines an equally valued premise of our criminal law, the presumption of innocence. See Coffin v. United States, 156 U.S. 432, 453 (1895) ("The principle that there is a presumption of innocence in favor of the accused is the undoubted law . . . and its enforcement lies at the foundation of the administration of our criminal law.").

184 Wolfish, 441 U.S. at 520.

${ }^{18 s}$ See notes $33-41$ and accompanying text above.

136 For example, see Williams v. United States, 341 U.S. 97, 102 \& n.1 (1951).

137 Stanley v. Illinois, 405 U.S. 645,656 (1972):

Indeed, one might fairly say of the Bill of Rights in general, and the Due Process Clause in particular, that they were designed to protect the fragile values of a vulnerable citizenry from the overbearing concern for efficiency and efficacy that may characterize praiseworthy government officials no less, and perhaps more, than mediocre ones. 13s Wolfish, 441 U.S. at 566 (Marshall, J. dissenting). Two recent cases complicate the arguments about the state of mind that must be shown in order to establish a due process violation. In Daniels, $106 \mathrm{~S}$. Ct. at 664 , the Court held that mere negligence by a state 
simply because an officer means well. It is also useful to note that in other areas of the law in which a liberty interest is affected without procedural protection, error or arbitrariness, and not maliciousness, is the concern of judicial review. ${ }^{138}$

Eliminating the "intent" and "severe injury" requirements of the Glick standard would do much to meet the criticisms of contemporary due process scrutiny. The remaining prong of the standard-the "disproportion" requirement-provides guidance in determining what conduct implicates the right to be free from punishment prior to conviction, but only if it is informed by current fourth amendment analysis of "reasonableness."

\section{Reasonableness As The Detainment Standard}

Only part of the difficulty in evaluating police use of force is eliminated by conceiving of it as a procedural matter and divesting it of requirements of malice and severe injury. A reformulation of the due process protection to be afforded detainees is also required in order to provide clearer guidance to courts and to detention officials.

A first source of guidance for such a reformulation should be the Supreme Court's treatment of allegations of excessive administrative regulations and restraints imposed upon detainees. In Bell $v$. Wolfish, in appraising detention practices that included routine strip and body cavity searches, a divided Court endeavored to outline such a standard. Justice Rehnquist, writing for the majority, said the question of whether due process rights are implicated turns on whether conduct by state officials amounts to punishment of the detainee. "Punishment" is distinguished from security restrictions and practices in that the latter involve a legitimate,

official is not sufficient to establish a deprivation under the due process clause, but it declined to state further "whether something less than intentional conduct, such as recklessness or 'gross negligence" " would suffice. Id. at 667 n.3. See also Davidson v. Cannon, 106 S. Ct. 668, 670 (1986).

When police use excessive force, however, the use of force is intentional, even though the officer may be negligent in believing that such force is justified. Since the Court has thus affirmed that intentional conduct may violate the due process clause, and has left open the possibility that "something less than intentional conduct" may do likewise, the Glick requirement of "malicious" or "shocking" conduct seems significantly more stringent than the Court's current view. This reasoning has been adopted by the view of the first court to apply fourteenth amendment scrutiny in light of Davidson. See Fernandez v. Leonard, 784 F.2d 1209, 1215-16 (1st Cir. 1986).

130. See Schall v. Martin, 467 U.S. 253, 274 (1983) (due process requires "sufficient protection against erroneous and unnecessary deprivations of liberty"); Goss v. Lopez, 419 U.S. 565, 574 (1985) ("[t]he Due Process Clause also forbids arbitrary deprivations of liberty"). 
nonpunitive governmental purpose. ${ }^{140}$

Requiring the articulation of a nonpunitive government purpose, however, does little more than import the "minimum rationality" standard from equal protection review to address quite different concerns associated with due process. ${ }^{141}$ As Justice Stevens insisted in Wolfish, "[t]he requirement that restraints have a rational basis provides an individual with virtually no protection against punishment."142 Such a standard, Justice Marshall maintained in dissent, serves only "to sanitize official motives and prohibit irrational behavior."143

This "legitimate nonpunitive purpose" standard is inadequate in the first instance as a matter of due process because when a court requires the state to articulate a "legitimate" or (to adopt the jargon of equal protection) a "rational" interest to justify particular detainment practices, only half of the due process equation has been considered. When assessing procedural regularity, the state's interest must be balanced against the grievousness of the individual's loss and the value of additional procedure prior to the deprivation. ${ }^{144}$ In excessive force cases the detainee's loss is undisputed; his interest in procedural regularity is not in securing a hearing additional to that afforded by his trial, but simply in ensuring that the trial itself is not rendered farcical by the imposition of punishment before the trial has begun.

The difficulty, of course, arises from defining "punishment," since all detention necessarily has punitive aspects. ${ }^{145}$ Justice Rehnquist referred approvingly to one standard by which to judge official conduct under the due process clause, an opinion that listed some of the Wolfish dissenters among its adherents. In Kennedy $v$. Mendoza-Martinez, ${ }^{146}$ the Court said it would appraise due process rights according to whether an affirmative disability imposed by the government was (recalling the only defensible part of the current standard ${ }^{147}$ ) excessive in relation to the purposes it served. ${ }^{148}$ The Court also indicated that it would consider whether

140 Wolfish, 441 U.S. at 561.

${ }^{161}$ See generally Gerald Gunther, Constitutional Law 676-704 (11th ed. 1985).

142441 U.S. at 585 (Stevens, J., dissenting).

${ }^{143}$ Id. at 565 (Marshall, J., dissenting).

${ }^{144}$ See, e.g., Mathews v. Eldridge, 424 U.S. 319, 335 (1976) (termination of social security disability benefits); Ingraham, 430 U.S. at 675 (corporal punishment).

${ }_{145}$ Wolfish, 441 U.S. at 586 (Stevens, J., dissenting).

146 372 U.S. 144 (1963) (holding that summary deportation proceedings for persons who left the country to evade military services violated due process).

${ }^{147}$ See notes $132-39$ and accompanying text above.

${ }^{168}$ Mendoza-Martinez, 372 U.S. at 168-69. 
the government's conduct could have been intended as punishment or whether it was but an incident of some other legitimate and nonpunitive governmental purpose. ${ }^{149}$

Although the Court continues to regard the factors identified in Mendoza-Martinez as "useful guideposts,"150 they in fact only serve to reintroduce the flawed Glick criteria of severity and intent. The inference that due process in excessive force cases should not be limited to severe intentional harms gains strength, oddly enough, from the Court's recent use of the Glick factors in appraising eighth amendment claims. In Whitley $v$. Albers, ${ }^{151}$ involving an excessive force allegation by a prison inmate who was shot and injured during a riot, the Court expressly adopted Judge Friendly's standard for pretrial detainees in Glick as the proper one to appraise what constitutes "cruel and unusual punishment" under the eighth amendment. ${ }^{162}$ Indeed, the Court noted with approval the district court's incorporation of Glick's three part standard into eighth amendment jurisprudence. ${ }^{153}$

The reasons for using Glick in cruel and unusual punishment cases, however, make clear that the Glick test sets an untenable standard for detainees' due process claims alleging excessive force. It is not "cruel and unusual" punishment that the Constitution proscribes for pretrial detainees, but any punishment at all. The Court has consistently held that it is "axiomatic and elementary" that states may not punish prior to an adjudication of guilt. ${ }^{154} \mathrm{~A}$ standard of protection for pretrial detainees that is more restrictive than Glick is therefore patently required-a standard that acknowledges the Court's insistence on a constitutional distinction between those simply detained on probable cause and those incarcerated following proof of guilt beyond a reasonable doubt.

One solution meets the need for a more restrictive standard: the reasonableness inquiry that is the hallmark of fourth amendment jurisprudence. The reasonableness standard is well-suited to incorporate the balancing of state and individual interests mandated by the procedural guarantees of the due process clause.

The Court's most recent and thoughtful endorsement of that

149 Id.

160 Wolfish, 441 U.S. at 538 .

151106 S. Ct. 1078 (1986).

182 Id. at 1085.

163 Id. The Court cited both Wolfish and Glick without reference to the constitutional distinction maintained between prisoners (the plaintiffs in Whitley) and pretrial detainees (the plaintiffs in Glick and Wolfish).

134 Coffin, 156 U.S. at 453. 
standard in Garner, and the many criticisms of Glick that prefer the greater objectivity and rigor of the fourth amendment standard, counsel for reasonableness as the standard of protection for detainees. It is true that the Court has been reluctant to accord detainees any semblance of "legitimate expectations of privacy" protected by the fourth amendment. ${ }^{155}$ But the institutional concern weighing against wholesale extension of that amendment's protection has been the need for institutional security, which necessitates that prison officials be able to control detainees' living areas and personal effects. ${ }^{168}$ These considerations do not favor enlarging the state's privilege to use force once an arrest has been effected-except perhaps in a small class of cases where force is necessary to preserve order, in which the use of force would be deemed reasonable anyway.

In short, the objectivity and administrability of the fourth amendment standard, the extant body of Supreme Court case law to inform its application, and the appeal of uniform limits to police force in similar contexts compel a reasonableness standard by which to appraise the use of force against detainees. Apart from this practical appeal, the reasonableness inquiry puts into effect the balancing of interests that the Court has held the due process clause requires. Finally, applying reasonableness analysis to detention conduct involving force resolves the anomaly of reducing the protection accorded to criminal suspects following arrest. ${ }^{157}$

The stricter "reasonableness" standard would not ignore the valid concerns of "institutional security." Although the Court in Wolfish suggested that deference to the requirements of prison administration might justify a standard for searches nearer to rationality than to reasonableness, ${ }^{158}$ this hardly upsets the argument for

155 See notes 106-11 and accompanying text above.

186 All of the prison cases discussed above at note 113 concern personal effects and searches. See Hudson v. Palmer, 468 U.S. 517 (1984); Wolfish, 441 U.S. at 520. Refusal to extend fourth amendment protection to these interests therefore presents no argument against a reasonableness standard for due process protection of bodily integrity.

${ }^{137}$ Applying the procedural analysis may require more than reasonableness; it may require rulemaking as well. Court-mandated rulemaking occurs in other contexts, most notably in cases where administrative agencies make decisions concerning economic benefits, and one commentator has expressed "some concern that we are more interested in the deprivation of economic benefits . . . than in the deprivation of liberty" when considering whether courts should require the promulgation of rules to limit police discretion. Gregory H. Williams, The Law and Politics of Police Discretion 68 (1984). See also Kenneth C. Davis, Discretionary Justice: A Preliminary Inquiry 80-96 (1969). Arguments about the appropriateness of rulemaking in the arrest and detainment contexts are, however, beyond the scope of this comment.

${ }^{138}$ See text at notes $140-43$ above. 
parallel treatment of force in the arrest and detainment contexts. Whereas for an arrest the reasonableness inquiry is colored by deference to an officer's judgment in a quickly-developing situation, in the detainment context this factor would be supplanted by due regard for what the Court has termed the "urgent problems of prison administration," "159 and thus similar fact patterns should generate similar results.

\section{CONCLUSION}

The application of fourth amendment standards to the use of force during arrest, as announced by the Supreme Court in Garner, should properly lead to adoption of that standard as the exclusive one in the context of arrest. Courts therefore should adopt a bifurcated approach, in which the fourth amendment insulates arrestees from excessive force, while the due process clause supplies protection from force once arrest is completed and detainment initiated.

Such an approach, which takes into consideration the comparative advantages of current fourth amendment doctrine, also mandates critical examination of the due process standard now applied by the courts of appeals to allegations of excessive police force against detainees. This standard is flawed both by the test it articulates and by its doctrinal reference. Properly understood, the due process clause should require no less justification when police use force in detention than the fourth amendment requires when they use such force in arrest.

Bradley M. Campbell 